\title{
PENINGKATAN HASIL BELAJAR SEJARAH MELALUI PEMBELAJARAN KOOPERATIF MODEL STAD KELAS X MIPA-3 SMA NEGERI 4 PEKALONGAN TAHUN 2016
}

\author{
Winardi \\ SMA Negeri 4 Pekalongan \\ Email: winardi.chofat@gmail.com
}

Abstrak

Tujuan penelitian ini adalah untuk meningkatkan hasil belajar peserta didik dengan penerapan pembelajaran kooperatif model STAD, khususnya kelas X MIPA-3 SMA Negeri 4 Pekalongan tahun pelajaran 2016/2017. Penelitian tindakan kelas ini dilaksanakan dalam dua siklus dan tiap siklus melalui perencanaan, pelaksanaan, pengamatan dan refleksi. Bila dibandingkan dengan pembelajaran sebelum penelitian, hasil penelitian menunjukkan terjadi peningkatan hasil belajar, pada siklus I dengan rata-rata nilai 81,01 terjadi kenaikan 9,70\% dari rata-rata nilai prasiklus 73,88 , kemudian hasil belajar sejarah siklus II dengan rata-rata nilai 84,70 terjadi kenaikan $4,50 \%$ dari rata-rata nilai siklus I 81,01. Simpulannya, pembelajaran kooperatif dengan model STAD (Student Teams Achievement Division) dapat meningkatkan hasil belajar peserta didik.

Kata Kunci : Hasil Belajar, Kooperatif, STAD (Student Teams Achievement Division)

\begin{abstract}
The purpose of this study is to improve learning outcomes of learners with the application of cooperative learning STAD model, especially class X Science 3 SMA Negeri 4 Pekalongan 2016/2017 academic year. This classroom action research is conducted in two cycles and each cycle through planning, observation and reflection. When compared with learning before the research, the results showed an increase in learning outcomes, in cycle I with the average value of 81.01 raised $9.70 \%$ of the average pre-cycle value of 73.88 , then the results of history learning cycle II with the average value of 84,70 raised $4.50 \%$ from average value of cycle I 81,01. Conclusion, cooperative learning with STAD model (Student Teams Achievement Division) can improve learners' learning outcomes.
\end{abstract}

Keywords: learning outcomens, cooperative, STAD 


\section{Pendahuluan}

Permasalahan yang dialami dalam proses pembelajaran di kelas yaitu masih rendahnya hasil belajar dan keaktifan peserta didik. Hal ini dikarenakan masih banyak tenaga pendidik dalam mendesain kelas dijumpai dalam menyampaikan materi pembelajaran masih monoton ceramah, tanya jawab dan pemberian tugas. Model ceramah yang diterapkan belum mampu menimbulkan keaktifan maupun kreativitas peserta didik. Sifat kritis yang ada pada peserta didik belum muncul secara maksimal dalam proses pembelajaran. Menurut Slavin (dalam Aqib, 2013: 13) salah satu model pengajaran yang sering digunakan dan praktis digunakan pendidik dalam mengajar adalah pembelajaran kooperatif. Tipe pembelajaran kooperatif yang digunakan dalam penelitian ini adalah model STAD merupakan salah satu model yang sederhana, menempatkan peserta didik dalam kelompokkelompok belajar dengan kemampuan yang heterogen dan cocok diterapkan di semua mata pelajaran, termasuk mata pelajaran sejarah.

Dalam pembelajaran kooperatif diharapkan adanya perubahan pada peserta didik untuk lebih baik. Perubahan belum tentu menjadikan segala sesuatu menjadi lebih baik, tetapi tanpa perubahan tak akan ada pembaharuan, dan tak akan ada kemajuan (Chen, 2011: 56). Dalam dunia pendidikan belajar merupakan suatu hal yang tidak bisa ditinggalkan oleh manusia karena pada hakekatnya setiap manusia hidup untuk belajar. Menurut Jenkins dan Unwin (dalam Uno, 2009: 17) yang mengatakan bahwa hasil belajar adalah pernyataan yang menunjukkan tentang apa yang mungkin dikerjakan siswa sebagai hasil dari kegiatan belajarnya. Jadi hasil belajar merupakan pengalaman-pengalaman belajar yang diperoleh siswa dalam 
bentuk kemampuan-kemampuan tertentu.

Menurut pendapat Bloom (dalam Suprijono, 2010: 6) hasil belajar mencakup kemampuan kognitif, afektif, dan psikomotorik, Domain kognitif adalah knowledge (pengetahuan, ingatan), comprehension (pemahaman, menjelaskan, meringkas, contoh), application (menerapkan), analysis (menguraikan, menentukan hubungan), synthesis (mengorganisasikan, merencanakan), dan evaluation (menilai). Domain afektif adalah receiving (sikap menerima), responding (memberikam tanggapan), valuing (nilai), organization (organisasi), characterization (karakterisasi). Domain psikomotorik meliputi initiatory, pre-routine, dan rountinizied. Psikomotorik juga mencakup keterampilan produktif, teknik, fisik, sosial, manajerial, dan intelektual.

Belajar dalam arti luas dapat diartikan sebagai proses yang memungkinkan timbulnya perubahan suatu tingkah laku sebagai hasil belajar dari terbentuk respon utama, degan syarat perubahan itu bukan karena kematangan atau perubahan yang bersifat sementara, sedangkan menurut Gagne (dalam Purwanto, 2007: 84) menyatakan bahwa belajar terjadi apabila suatu situasi stimulus bersama dengan isi ingatan mempengaruhi siswa sedemikian rupa sehingga perbuatannya berubah dari waktu sebelum ia mengalami situasi itu waktu sesudah ia mengalami situasi tadi. Hasil belajar peserta didik adalah kemampuan yang utuh yang mencakup kemampuan kognitif, kemampuan psikomotorik, dan kemampuan afektif atau perilaku.

Penilaian hasil belajar adalah kegiatan yang bertujuan untuk mengetahui sejauh mana proses belajar dan pembelajaran telah berjalan secara efektif. Hasil belajar adalah perubahan perilaku secara keseluruhan bukan hanya salah satu aspek potensi kemanusiaan saja, artinya hasil pembelajaran dikategorikan oleh 
para pakar pendidikan sebagaimana tersebut di atas tidak dilihat secara fragmentaris atau terpisah, melainkan komprehensif. Menurut Benyamin S. Bloom (dalam Chatarina dan Rifa'i, 2011: 86) ada tiga taksonomi yang disebut dengan ranah belajar. Ranah belajar tersebut adalah sebagai berikut: (1) ranah kognitif berkaitan dengan hasil berupa pengetahuan, kemampuan, dan kemahiran intelektual. Ranah kognitif ini mencakup kategori pengetahuan (knowledge), pemahaman (Comprehension), penerapan (application), analisis, sintesis, dan penilaian (evaluation); (2) Ranah afektif berkaitan dengan perasaan, sikap, minat, dan nilai. Kategori tujuan peserta didikan afektif adalah penerimaan (receiving), penanggapan (responding), penilaian (valuing), pengorganisasian (organization), pembentukan pola hidup (Organization by a value complex); (3) Ranah psikomotorik berkaitan dengan kemampuan fisik seperti keterampilan motorik dan syaraf, manipulasi objek, dan koordinasi syaraf. Dari pengertian tersebut di atas dapat disimpulkan bahwa hasil belajar adalah gambaran tingkat penguasaan peserta didik terhadap sasaran belajar pada topik bahasan yang dipelajari berupa perubahan perilaku belajar siswa meliputi ranah kognitif, afektif dan psikomotorik yang dapat diukur dengan beberapa alat tes.

Menurut Suprijono (2010: 45) menyatakan bahwa: "Model pembelajaran adalah pola yang digunakan sebagai pedoman dalam merencanakan pembelajaran di kelas maupun tutorial. Model pembelajaran dapat didefinisikan sebagai kerangka konseptual yang melukiskan prosedur sistematis dalam mengorganisasikan pengalaman belajar untuk mencapai tujuan belajar". Model merupakan interpretasi terhadap hasil observasi dan pengukuran yang diperoleh dari beberapa sistem model pembelajaran merupakan landasan praktik pembelajaran hasil penurunan teori 
psikologi pendidikan dan teori belajar yang dirancang berdasarkan analisis terhadap implementasi kurikulum dan implikasinya pada tingkat operasional di kelas model pembelajaran dapat diartikan pula sebagai pola yang digunakan untuk penyusunan kurikulum, mengatur materi, dan memberi petunjuk kepada pendidik di kelas". Menurut Joyce, (dalam Trianto, 2010: 5) menyatakan bahwa: "Model pembelajaran adalah suatu perencanaan atau suatu pola yang digunakan sebagai pedoman dalam merencanakan pembelajaran di kelas atau pembelajaran dalam tutorial dan untuk menentukan perangkat-perangkat pembelajaran termasuk di dalamnya buku-buku, film, komputer, kurikulum, dan lain-lain.

Menurut Davidson (dalam Trianto 2010: 62) sejumlah implikasi positif dalam pembelajaran dengan menggunakan strategi belajar kooperatif yaitu sebagai berikut: (1) kelompok kecil memberikan dukungan social untuk belajar. Kelompok kecil membentuk suatu forum di mana peserta didik menanyakan pertanyaan, mendiskusikan pendapat, belajar dari pendapat orang lain, memberikan kritik yang membangun dan menyimpulkan pertemuan mereka dalam bentuk tulisan; (2) kelompok kecil menawarkan kesempatan untuk sukses bagi semua peserta didik. Interaksi dalam kelompok dirancang untuk semua anggota mempelajari konsep dan strategi pemecahan masalah; (3) suatu masalah idenya cocok untuk didiskusikan secara kelompok, sebab memiliki solusi yang dapat didemonstrasikan secara obyektif. Seorang peserta didik dapat mempengaruhi peserta didik lain dengan argumentasi yang logis; (4) peserta didik dalam kelompok dapat membantu peserta didik lain untuk menguasai masalahmasalah dasar dan prosedur perhitungan yang perlu dalam konteks permainan, teka-teki, atau pembahasan masalah-masalah 
yang bermanfaat; (5) ruang lingkup materi dipenuhi oleh ide-ide menarik dan menantang bila didiskusikan.

Model pembelajaran dapat didefinisikan sebagai kerangka konseptual yang melukiskan prosedur sistematis dalam mengorganisasikan pengalaman belajar untuk mencapai tujuan belajar (Suprijono, 2010: 45). Model Pembelajaran yang digunakan peneliti ini adalah model pembelajaran kooperatif tipe STAD (Student Teams Achievement Division), model ini merupakan salah satu tipe dari model pembelajaran kooperatif dengan menggunakan kelompok-kelompok kecil dengan jumlah anggota tiap kelompok 6-7 orang peserta didik secara heterogen (dalam satu kelompok ada yang memiliki kecakapan tinggi, sedang dan kurang).

Menurut Slavin (dalam Aqib, 2013: 20) menyatakan bahwa model Student Teams-Achievement Divisioons (STAD) atau tim siswa kelompok prestasi merupakan model pembelajaran yang sederhana dan cocok untuk diterapkan setiap mata pelajaran termasuk sejarah. Adapun langkah-langkah model pembelajaran kooperatif tipe STAD (Student Teams Achievement Division) sebagai berikut: (1) membentuk kelompok yang anggotanya 6-7 siswa secara heterogen (campuran menurut prestasi, jenis kelamin, suku, dan lain-lain); (2) pendidik menyajikan pelajaran; (3) pendidik memberi tugas kepada kelompok untuk dikerjakan oleh anggota-anggota kelompok. Anggotanya tahu menjelaskan pada anggota lainnya sampai semua anggota dalam kelompok itu mengerti; (4) pendidik memberi kuis kepada seluruh siswa. Pada saat menjawab kuis/pertanyaan tidak boleh saling membantu; (5) memberi evaluasi; (6) memberikan kesimpulan. 


\section{Metode Penelitian}

Penelitian tindakan kelas ini dilaksanakan di SMA Negeri 4 Pekalongan, jalan HOS. Cokroaminoto, no. 383.A Pekalongan Selatan yang direncanakan 2 siklus selama 4 (empat) bulan dimulai dari bulan Januari 2017 s/d April 2017. Subjek penelitian ini dilaksanakan di kelas X MIPA-3 semester 2 tahun pelajaran 2016/2017 sejumlah 34 peserta didik, dengan rincian putra 14 peserta pendidik, putri 20 peserta pendidik dengan karakteristik secara umum dalam pembelajaran peserta pendidik kurang aktif dan mudah jenuh.

Sumber data dari penelitian ini berasal dari peserta didik: hasil pengamatan proses belajar mengajar dan hasil evaluasi (ulangan prasiklus, ulangan harian siklus I dan ulangan harian siklus II) dan pendidik: hasil observasi/pengamatan dalam kegiatan pembelajaran.

Penelitian ini menggunakan teknik pengumpulan data dengan tes dan non tes.Teknik tes dilaksanakan dengan tes ulangan harian (post tes). Sedangkan teknik non tes dilaksanakan dengan melalui observasi meminta bantuan guru lain sebagai observer, yang dilakukan untuk mengetahui partisipasi peserta pendidik dan pendidik dalam proses pembelajaran pada kompetensi dasar akulturasi dan perkembangan budaya Islam serta proses integrasi nusantara . Alat pengumpulan data melalui: instrumen 1: soalsoal tes dan instrumen 2: lembar pengamatan.

Analisis data dilakukan dengan menggunakan analisis deskriptif komporatif yaitu membandingkan nilai tes siklus 1 dan 2 dengan indikator kinerja. Penelitian deskriptif diartikan sebagai suatu penelitian yang berusaha mendiskripsikan suatu peristiwa secara sistematis sesuai dengan apa adanya (Dantes, 2012: 51). Sedangkan menurut Sudarwan Danim (2002: 41-42) langkah 
umum penelitian deskriptif adalah: (1) mengidentifikasi masalah, (2) mendefinisikan masalah secara spesifik, (3) merumuskan rancangan atau desain pendekatan, 4) mengumpulkan dan menganalisis data, (5) menyusun laporan penelitian. Analisis data pada penelitian ini dilakukan secara kuantitatif, hasil tes dianalisis secara kuantitatif berdasarkan persentase.

Ketuntasan peserta didik dikatakan tuntas dalam pembelajaran jika nilai telah mencapai minimal $\geq 75$ sesuai dengan ketentuan KKM mata pelajaran ejarah SMA Negeri 4 Pekalongan dengan nilai KKM = 75. Menurut Aqib, dkk. (2009: 41) rumus perhitungan nilai ketuntasan adalah :

Nilai $=\frac{\Sigma \text { Skor yang diperoleh peserta didik }}{\Sigma \text { Skor maksimal }}$.

Dalam suatu kelas dinyatakan telah mencapai ketuntasan hasil belajar klasikal apabila $80 \%$ dari jumlah peserta pendidik yang telah tuntas secara individu mencapai kriteria ketuntasan minimal (KKM) mata pelajaran sejarah di SMA Negeri 4 Pekalongan, yaitu 75 (tujuh puluh lima). Rumus perhitungannya adalah :

Tingka Ketuntasan $=\frac{\Sigma \text { Banyaknya peserta didik yang tuntas }}{\Sigma \text { Jumlah peserta tes }} \mathrm{X} 100 \%$

Sesuai dengan desain perencanaan Penelitian Tindakan Kelas, prosedur penelitian ini menggunakan prosedur siklus. Penelitian dilakukan dalam 2 siklus, secara umum, terdapat empat langkah dalam melakukan penelitian tindakan kelas, yaitu perencanaan tindakan, pelaksanaan tindakan, pengamatan, dan refleksi (Suyadi, 2011:49).

\section{Hasil dan Pembahasan}

Pada proses pembelajaran prasiklus di kelas X MIPA-3 SMA Negeri 4 Pekalongan pada kompetensi dasar kehidupan awal masyarakat Indonesia, pendidik masih menggunakan 
metode konvensional yaitu dengan ceramah dan tanya jawab atau masih teacher oriented. Pendidik belum menggunakan lembar observasi atau pengamatan pada peserta didik. Kriteria ketuntasan minimal (KKM) mata pelajaran sejarah adalah nilai 75 , sedangkan hasil prasiklus test awal diperoleh nilai rata-rata 73,88 , peserta didik yang tuntas atau mendapat nilai $\geq 75$ berjumlah 23 peserta didik $(67,65 \%)$, sedangkan peserta didik tidak tuntas atau mendapat nilai $<75$ berjumlah 11 peserta didik $(32,35 \%)$. Dari hasil evaluasi tersebut masih jauh dari harapan yang diinginkan yaitu peserta didik yang tuntas belajar klasikal $80 \%$ dengan kriterian ketuntasan minimal nilai 75 .

Kegiatan siklus I, pelaksanaan pembelajaran pada materi akulturasi dan perkembangan budaya Islam sudah menerapkan pendekatan kooperatif dengan model STAD (Student Teams-Achievement Divisioons) penelitian kelas dimulai dari siklus I terdiri dari perencanaan, pelaksanaan, pengamatan dan refleksi tindakan. Setiap siklus terdiri 3 kali pertemuan dan dipertemuan terakhir dilaksanakan evaluasi. Ada pun langkah-langkah model STAD (Student TeamsAchievement Divisioons) dalam pembelajaran pada tiap pertemuan yaitu; (1) kegiatan pendahuluan, (2) kegiatan inti, kegiatan pembelajaran dengan menerapkan model pembelajaran STAD ada 6 langkah, yakni: (a) membentuk kelompok yang anggotanya 6-7 siswa secara heterogen (campuran menurut prestasi, jenis kelamin, suku, dan lainlain); (b) pendidik menyajikan pelajaran; (c) pendidik memberi tugas kepada kelompok untuk dikerjakan oleh anggota-anggota kelompok. Anggotanya tahu menjelaskan pada anggota lainnya sampai semua anggota dalam kelompok itu mengerti; (d) 
pendidik member kuis/pertanyaan kepada seluruh siswa. Pada saat menjawab kuis/pertanyaan tidak boleh saling membantu; (e) memberi evaluasi; (f) memberikan kesimpulan; dan (3) kegiatan penutup.

Pada siklus I dilaksanakan pada tanggal 8, 15, 22 Februari 2017, dimana tanggal 8, 15 Februari 2017 untuk kegiatan pembelajaran STAD dan tanggal 22 Februari 2017 untuk evaluasi terhadap hasil belajar peserta didik dengan 25 soal pilihan ganda. Hasil pada siklus I setelah diadakan observasi dan penilaian dapat dilihat seperti tabel 1 .

Tabel 1. Hasil Ketuntasan Belajar Siklus I

\begin{tabular}{|l|c|c|}
\hline Rentang Nilai & $\begin{array}{c}\text { Jumlah Peserta } \\
\text { Didik }\end{array}$ & Keterangan \\
\hline Tuntas Belajar & 26 & $76,47 \%$ \\
\hline $\begin{array}{l}\text { Tuntas Tidak } \\
\text { Belajar }\end{array}$ & 8 & $23,53 \%$ \\
\hline Nilai Rata-rata & & 81.05 \\
\hline Daya Serap & & $81.05 \%$ \\
\hline
\end{tabular}

Berdasarkan tabel 1 sebagai berikut : (1) nilai rata-rata kelas 81.05 sudah mencapai kriteria ketuntasan minimal yaitu 75 ; (2) 26 peserta didik tuntas belajar atau 76,47\%, 8 peserta didik tidak tuntas atau 23,53\%; (3) nilai tertinggi : 92, diraih 5 orang peserta didik dan nilai terendah 60, diraih oleh 1orang peserta didik; (4) nilai ketuntasan klasikal yang diharapkan $80 \%$ dari KKM 75 belum tercapai karena masih 76,47 \%.

Hasil pengamatan yang terdiri atas dari beberapa komponen aspek afektif: (a) aspek kerjasama sebagai berikut: 4 peserta didik dengan persentase $(11,77 \%)$ mendapatkan kategori sangat baik, 12 peserta didik dengan persentase $(35,29 \%)$ mendapatkan kategori 
baik dan 18 peserta didik dengan persentase (52,94\%) mendapatkan kategori cukup, rata-rata aspek kerja sama 76,24 apabila dikualitatifkan menjadi nilai B (Baik); (b) aspek keaktifan sebagai berikut: 8 peserta didik dengan persentase $(23,53 \%)$ mendapatkan kategori sangat baik, 18 peserta didik dengan persentase $(52,94 \%)$ mendapatkan kategori baik dan 8 peserta didik dengan persentase (23,53\%) mendapatkan kategori cukup, sedang rata-rata aspek keaktifan 80,12 apabila dikualitatifkan menjadi nilai B (Baik); (c) aspek tanggung jawab sebagai berikut: 2 peserta didik dengan persentase (5,88\%) mendapatkan kategori sangat baik, 31 peserta didik dengan persentase (91,18\%) mendapatkan kategori baik dan 1 peserta didik dengan persentase (2,94\%) mendapatkan kategori cukup, sedang rata-rata aspek bertanggung jawab 80,00 apabila dikualitatifkan menjadi nilai $\mathrm{B}$ (Baik); (d) aspek psikomotorik sebagai berikut: 9 peserta didik dengan persentase $(26,47 \%)$ mendapatkan kategori sangat baik, 14 peserta didik dengan persentase (41,18\%) mendapatkan kategori baik dan 11 peserta didik dengan persentase (32,35\%) mendapatkan kategori cukup, sedang rerata aspek psikomotorik 79,09 apabila dikualitatifkan menjadi nilai B (Baik).

Berdasarkan hasil observasi dan ulangan harian siklus I di atas maka dapat disimpulkan sebagai berikut : (1) rata-rata nilai hasil observasi (kerjasama, keaktifan, tanggung jawab dan psikomotorik) dengan nilai baik; (2) rata-rata nilai hasil ulangan harian sudah mencapai kriteria ketuntasan minimal; (3) persentase klasikal kriteria ketuntasan minimal tidak tercapai sesuai indikator yang ditetapkan 80\%; (4) berdasarkan hasil tersebut maka perlu diadakan tindakan selanjutnya pada siklus II.

Adapun tidak berhasilnya pada siklus I, disebabkan antara lain : (a) peserta didik tidak terbiasa dilatih untuk menggunakan 
model diskusi; (b) model pembelajaran STAD belum dikenal secara umum oleh peserta didik; (c) materi tidak optimal dipelajari oleh peserta didik; (d) pada pelaksanaan tindakan di siklus I, peneliti melakukan tindakan dengan mempertimbangkan hasil siklus I yakni bahwa hasil evaluasi melalui ulangan di siklus I yang mendapat nilai tidak tuntas akan peneliti perhatikan lebih baik dan diberikan kesempatan untuk aktif dalam pembelajaran di kelas.

Kegiatan siklus II dilaksanakan pada tanggal 15, 22, 29 Maret 2017, dimana pada tanggal 15, 22 Maret 2017 dengan materi proses integrasi nusantara tetap akan menggunakan model STAD, pada tanggal 29 Maret 2017 untuk evaluasi hasil belajar siklus II dengan soal 25 pilihan ganda. Hasil belajar pada siklus II dapat dilihat tabel 2 sebagai beikut :

Tabel 2. Hasil Ketuntasan Belajar Siklus II

\begin{tabular}{|l|c|c|}
\hline Rentang Nilai & Jumlah Peserta & Keterangan \\
\hline Tuntas Belajar & 29 & $86,30 \%$ \\
\hline Tuntas Tidak & 5 & $14,70 \%$ \\
\hline Nilai Rata-rata & & 84,70 \\
\hline Daya Serap & & $84,70 \%$ \\
\hline
\end{tabular}

Berdasarkan hasil ulangan harian siklus II di atas dapat disimpulkan sebagai berikut: (1) nilai rata-rata kelas 84,70 maka nilai rata-rata kelas menunjukkan sudah mencapai kriteria ketuntasan minimal yaitu 75; (2) jumlah 29 peserta didik tuntas belajar atau $86,30 \%$, sedangkan 5 peserta didik tidak tuntas atau $14,70 \%$; (3) nilai tertinggi : 96, diraih 1 orang peserta didik dan nilai terendah 64, diraih oleh 1 orang peserta didik; (4) nilai ketuntasan klasikal yang diharapkan $80 \%$ dari kriteria ketuntasan minimal 75 sudah tercapai yaitu $86,30 \%$.

Pembahasan hasil observasi/pengamatan siklus II yang terdiri dari komponen: (a) aspek kerjasama sebagai berikut: 7 
peserta didik dengan persentase $(20,59 \%)$ mendapatkan kategori sangat baik, 19 peserta didik dengan persentase (55,88\%) mendapatkan kategori baik dan 8 peserta didik dengan persentase $(23,53 \%)$ mendapatkan kategori cukup, sedangkan rata-rata aspek kerja sama 78,35 apabila dikualitatifkan menjadi nilai B (Baik); (b)) aspek keaktifan sebagai berikut: 8 peserta didik dengan persentase $(23,53 \%)$ mendapatkan kategori sangat baik, 22 peserta didik dengan persentase (64,71\%) mendapatkan kategori baik dan 4 peserta didik dengan persentase $(11,76 \%)$ mendapatkan kategori cukup, sedang rata-rata aspek keaktifan 83,06 apabila dikualitatifkan menjadi nilai B (Baik), (c) aspek tanggung jawab sebagai berikut: 8 peserta didik dengan persentase $(23,53 \%)$ mendapatkan kategori sangat baik, 24 peserta didik dengan persentase $(70,59 \%)$ mendapatkan kategori baik dan 2 peserta didik dengan persentase $(5,88 \%)$ mendapatkan kategori cukup, sedang rata-rata aspek tanggung jawab 81,65 apabila dikualitatifkan menjadi nilai B (Baik); (d) aspek psikomotorik sebagai berikut: 9 peserta didik dengan persentase (26,50\%) mendapatkan kategori sangat baik, 17 peserta didik dengan persentase (50\%) mendapatkan kategori baik dan 8 peserta didik dengan persentase $(23,50 \%)$ mendapatkan kategori cukup, sedang rata-rata aspek psikomotorik 80,98 apabila dikualitatifkan menjadi nilai B (Baik).

Dari hasil observasi (kerja sama, keaktifan, tanggung jawab dan psikomotorik) serta hasil ulangan siklus II di atas maka dapat dipaparkan sebagai berikut : (a) rata-rata nilai hasil pengamatan baik; (b) rata-rata nilai hasil ulangan sudah mencapai kriteria ketuntasan minimal; (c) persentase klasikal kriteria ketuntasan minimal tercapai sesuai indikator yang ditetapkan $80 \%$. 
Pembahasan antar siklus, penelitian ini dilakukan hanya satu kelas yaitu di kelas X MIPA-3 dengan jumlah peserta didik 34 yang akan dilaksanakan melalui siklus I dan siklus II. Kondisi awal peserta didik banyak yang belum mencapai ketuntasan belajar kritria ketuntasan minimal yaitu 11 peserta didik dan yang sudah mencapai ketuntasan belajar hanya berjumlah 23 peserta didik. Melalui kegiatan proses belajar menggunakan model pembelajaran kooperatif model STAD (Student Teams Achievement Division) melibatkan peserta didik dan menuntut peserta didik untuk melakukan aktivitas belajar. Peserta didik diajak untuk lebih interaksi, aktif, kritis, kreatif, dan lebih perhatian dalam menerima pelajaran atau materi yang dibahas. Pendidik di sini berfungsi sebagai mediator dengan memantau dan mengatur jalannya pembelajaran peserta didik di dalam kelas.Pendidik menciptakan suasana belajar dalam kelas yang menimbulkan aktivitas peserta didik sehingga tercipta proses belajar yang baik dan akan menyebabkan interaksi di dalam kelas yang dapat meningkatkan aktivitas dan hasil belajar peserta didiknya.

Hasil ulangan harian pada siklus I dan siklus II terjadi kenaikan yang dicapai oleh peserta didik, hal ini dapat dilihat seperti dalam tabel 3 di bawah ini.

Tabel 3. Rekap hasil belajar Siklus I, Siklus II dan Refleksi :

\begin{tabular}{|l|l|l|l|l|}
\hline No. & \multicolumn{1}{|c|}{ Uraian } & \multicolumn{1}{|c|}{ Siklus I } & \multicolumn{1}{c|}{ Siklus II } & \multicolumn{1}{c|}{ Refleksi } \\
\hline 1. & Hasil & Ulangan & Ulangan harian & Diskriptif \\
& Aktifitas & harian pada & pada siklus II : & komparatif: \\
& Peserta & kondisi & a. Nilai & Nilai terendah \\
& didik & siklus I: & Tertinggi: & meningkat 6,66\% \\
& & a. Nilai & 100 & dari 60 menjadi \\
& & Tertinggi: & b. Nilai & 64. \\
& 92 & Terendah: 64 & Nilai Tertinggi \\
& & b. Nilai & c. Rata-rata : & tidak terjadi \\
& & Terendah:6 & 84,70 peningkatan \\
& & 0 & d. Daya Serap: & $8,42 \%$ dari 92 \\
\hline
\end{tabular}




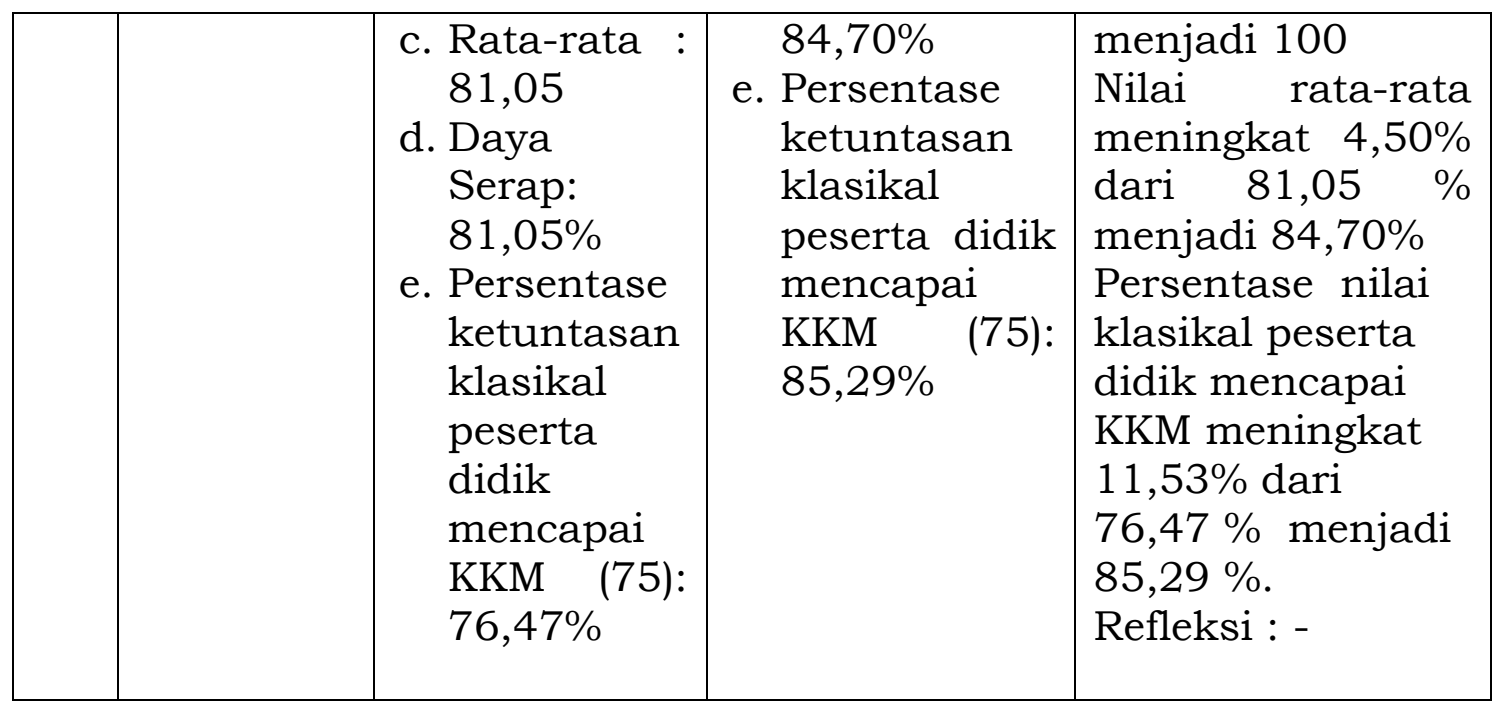

Berdasarkan data tabel 3 dapat dibuktikan peningkatan hasil belajar sejarah melalui pembelajaran kooperatif model STAD (Student Teams Achievement Division) X MIPA-3 SMA Negeri 4 Pekalongan semester 2 tahun pelajaran 2016/2017 dalam kompetensi dasar akulturasi dan perkembangan budaya Islam serta materi proses integrasi nusantara lebih efektif jika dibandingkan sebelum menggunakan pembelajaran kooperatif model STAD. Hal ini dapat ditunjukkan dari hasil analisis data yang diperoleh : hasil penelitian menunjukkan bahwa nilai ulangan pada kompetensi dasar akulturasi dan perkembangan budaya Islam, setelah dianalisis data bahwa hasil belajar sejarah pada siklus I dengan rata-rata nilai 81,01 terjadi kenaikan 9,70\% dari rata-rata nilai prasiklus 73,88. Hasil ketuntasan klasikal siklus I dengan persentase 76,47\% terjadi kenaikan 13,03\% dari hasil ketuntasan klasikal prasiklus dengan persentase 67,65\%. Kemudian hasil belajar sejarah siklus II pada materi proses integrasi nusantara dengan rata-rata nilai 84,70 terjadi kenaikan $4,50 \%$ dari rata-rata nilai siklus I 81,01. Sedangkan ketuntasan klasikal pada siklus II dengan persentase 85,29\% terjadi kenaikan $11,53 \%$ dari hasil ketuntasan klasikal I dengan persentase 
76,47\%. Hasil nilai aspek afektif peserta didik pada siklus I meliputi aspek kerja sama kelompok dengan rata-rata nilai persentase $76,24 \%$, aspek keaktifan dengan rata-rata nilai persentase $80,12 \%$, aspek tanggung jawab dengan rata-rata nilai persentase $80,00 \%$ sedangkan aspek psikomotorik peserta didik rata-rata nilai $79,02 \%$. Hasil nilai aspek afektif peserta didik pada siklus II meliputi aspek kerja sama kelompok dengan rata-rata nilai persentase $78,82 \%$, aspek keaktifan dengan rata-rata nilai persentase $82,94 \%$, aspek tanggung jawab dengan rata-rata nilai persentase $81,65 \%$ sedangkan aspek psikomotorik peserta didik nilai rata-rata $80,98 \%$.

Peningkatan hasil belajar dari segi afektif dan psikomotorik peserta didik terlihat lebih baik dalam proses pembelajaran, hal ini dapat dilihat dengan adanya peningkatan hasil belajar, aspek afektif dan aspek psikomotorik peserta didik. Pada aspek afektif skor persentase tertinggi yaitu $92 \%$ dengan skor persentase ratarata $83,06 \%$, hal ini berarti hasil belajar afektif peserta didik mempunyai kriteria sikap baik, sedangkan pada aspek psikomotorik skor persentase tertinggi yaitu 93,33\% dengan skor persentase rata-rata $80,98 \%$, hal ini berarti hasil belajar aspek psikomotorik peserta didik juga mempunyai kriteria sikap baik. Berdasarkan penelitian dan uraian di atas, dapat disimpulkan bahwa menggunakan model pembelajaran STAD efektif dalam meningkatkan nilai hasil belajar dan nilai afektif pada peserta didik kelas XMIPA-3 SMA Negeri 4 Pekalongan semester 2 tahun pelajaran 2016/2017. Oleh karena itu proses kegiatan belajar mengajar menggunakan pembelajaran kooperatif model STAD dapat dijadikan salah satu alternatif model pembelajaran di kelas lain. 


\section{KESIMPULAN DAN SARAN}

Berdasarkan hasil penelitian dan pembahasan dapat diambil kesimpulan penggunaan pembelajaran kooperatif model STAD ( Student Teams Achievement Division) pada kompetensi dasar akulturasi dan perkembangan budaya Islam serta proses integrasi nusantara di kelas X MIPA-3 SMA Negeri 4 Pekalongan dapat meningkat dari nilai ulangan harian rata-rata 73,88 pada saat pretest (pra siklus) tingkat ketuntasan kelas 67,65\%, pada siklus I nilai ulangan harian rata-rata 81,05 tingkat ketuntasan kelas $76,47 \%$, pada siklus II nilai ulangan harian rata-rata menjadi 84,70 sedangkan tingkat ketuntasan kelas 85,29\%. Secara statistik dapat dibuktikan adanya peningkatan hasil belajar melalui pembelajaran kooperatif model STAD terhadap nilai hasil belajar pada mata pelajaran sejarah pada peserta didik kelas $\mathrm{X}$ MIPA-3 SMA Negeri 4 Pekalongan. Penggunaan pembelajaran kooperatif model STAD terhadap hasil belajar sejarah kelas $\mathrm{X}$ MIPA-3 SMA Negeri 4 Pekalongan, selain dapat meningkatkan hasil belajar dari segi kognitif (pengetahuan) tetapi juga peserta didik terlihat lebih aktif dalam proses pembelajaran, hal ini dapat dilihat dengan adanya peningkatan hasil belajar dari aspek afektif dan aspek psikomotorik peserta didik.

Berdasarkan hasil penelitian disarankan agar penerapan pembelajaran kooperatif model STAD disosialisasikan dan digunakan sebagai alternatif dalam pembelajaran sejarah di SMA maupun SMK, untuk meningkatkan hasil belajar peserta didik. Selain itu dalam penerapan model ini seorang pendidik perlu senantiasa mengawasi kelas $\mathrm{X}$ MIPA-3 untuk memberikan memotivasi keaktifan peserta didik dan memberi bimbingan secara individu maupun kelompok. Penelitian lebih lanjut perlu dilakukan sebagai pengembangan diri sehingga dapat 
mengembangkan penelitian dalam ruang lingkup yang lebih luas. Semoga dari hasil penelitian ini dapat dipergunakan sebagai referensi bagi pendidik yang akan melakukan penelitian kelas dengan model STAD (Student Teams Achievement Division) khususnya bagi pendidik SMA Negeri 4 Pekalongan dan bagi pendidik lain pada umumnya.

\section{DAFTAR PUSTAKA}

Aqib, Zainal dkk. 2009. Penelitian Tindakan Kelas untuk SD, SLB dan TK. Bandung: Yrama Widya.

Aqib, Zainal. 2013. Metode-Metode, Media, dan Strategi Pembelajaran Kontekstual (Inovatif), Bandung: Yrama Widya.

Chatarina dan Rifa'I, Achmad. 2011. Psikologi Pendidikan. Semarang: UNNES.

Chen, Febe. 2011. "Competetence for Success" Maksimalkan Potensi Diri Menjadi Profesional Berkompeten 'Karakter dan Motivasi". Jakarta: Ikrar Mandiri Abadi

Prenada Media Press.

Danim, Sudarwan. 2002. Menjadi Peneliti Kualitatif. Bandung : Pustaka Setia.

Dantes, Nyoman. 2012. Metode Penelitian. Yogyakarta: C.V Andi Offset.

Dimyati dan Mudjiono. 2009. Belajar dan Pembelajaran. Jakarta: Rineka Cipta

Purwanto, Ngalim. 2007. Psikologi Pendidikan. Bandung: Remaja Rosdakarya.

Suprijono, Agus. 2010. Cooperatif Learning Teori dan Aplikasi PAIKEM. Yogyakarta: Pustaka Pelajar.

Suyudi. 2011. Panduan Penelitian Tindakan Kelas. Yogyakarta : DIVA Pers. 
JIPSINDO No. 1, Volume 5, Maret 2018

Trianto. 2010. Mendesain Model Pembelajaran Inovatif-Progresif. Jakarta:

Uno, Hamzah. 2011. Teori Motivasi dan Pengukurannya.Jakarta: Bumi Aksara

Yogyakarta: Pustaka Pelajar. 